\title{
A survey on the performance and status of disseminated elite N'Dama cattle breeding bulls at the Multiplier tier of an Open Nucleus Breeding Scheme in The Gambia for the period 2011-2019
}

\author{
Arss Secka*, Lamin Camara, Momodou Jeng and Olawale Olaniyan \\ West Africa Livestock Innovation Centre, PMB 14, Banjul, The Gambia
}

\begin{abstract}
The objectives of this survey conducted in 2020 were to profile Multiplier farmers, assess the performance of disseminated N'Dama breeding bulls at the multiplier cattle herds, and inquire about cattle health and production challenges. Thirty-three farmers living in 33 villages in 5 regions of The Gambia who received 52 elite N'Dama breeding bulls from the West Africa Livestock Innovation Centre (WALIC) Nucleus tier were interviewed.

The results showed that the disseminated bulls' performance is generally satisfactorily as asserted by 28 respondents. Twentyeight respondents reported that the bulls were healthier, 31 ascribed these bulls with stronger libido, 20 asserted that female offspring from these bulls produced more milk, and 26 claimed that offspring had a faster growth rate. A total of 473 calves have been sired by these bulls thus far. However, only 19 bulls are currently present at the multiplier herds due to the exit of 33 bulls arising from various causes. Cattle production challenges reported by farmers included decreasing grazing lands, rampant bush fires, and inadequate watering points; whilst listed health constraints included inadequate access to veterinary drugs and trypanosomiasis disease prevalence. The multiplication of the disseminated breeding bulls at the Multiplier tier has progressed well in terms of sired offspring, but further transfer to the Commercial Farmer tier is slow. This situation calls for more sensitization of farmers, increased visibility of the breeding programme, and utilization of other reproductive techniques such as artificial insemination to reach more cows for enhanced genetic improvement and productivity.
\end{abstract}

Keywords: Performance, ONBS, Multiplier tier, N'Dama cattle bulls, The Gambia

Citation: Secka, A., Camara, L., Jeng, M., Olaniyan, O. (2022). A survey on the performance and status of disseminated elite N'Dama cattle breeding bulls at the Multiplier tier of an Open Nucleus Breeding Scheme in The Gambia for the period 2011-2019. Genetic Resources 3 (5), 1-9. doi: 10.46265/genresj.SVVL8053.

(C) Copyright 2022 the Authors.

This is an open access article distributed under the terms of the Creative Commons Attribution License (CC BY 4.0), which permits unrestricted use, distribution, and reproduction in any medium, provided the original author and source are

credited.

\section{Introduction}

Developing countries like The Gambia have a gross deficit in both beef and milk products as increasing demand far outweighs local production. Due to its tolerance to trypanosomiasis disease, N'Dama cattle is the most widely used breed by farmers in mixed production systems practised in The Gambia, a country which lies within the tsetse infested belt of the African region (Secka et al, 2015; Olaniyan et al, 2021). N'Dama cattle breed tolerance to trypanosomiasis disease, as

*Corresponding author: Arss Secka (seckaarss@gmail.com) well as their heat tolerance, good draught power and ability to thrive on low-quality feeds, make them highly valuable in such a context. Furthermore, this multidisease resistant N'Dama cattle has been recommended for low-input traditional African farming systems in areas where trypanosomiasis, ticks and tick-borne diseases are constraints to livestock production (Mattioli et al, 1998).

Improving the productivity of N'Dama cattle under low-input production systems through genetic improvement complemented with optimum management is a viable strategy for increasing local meat and milk production using indigenous livestock breeds (Figure 1). 


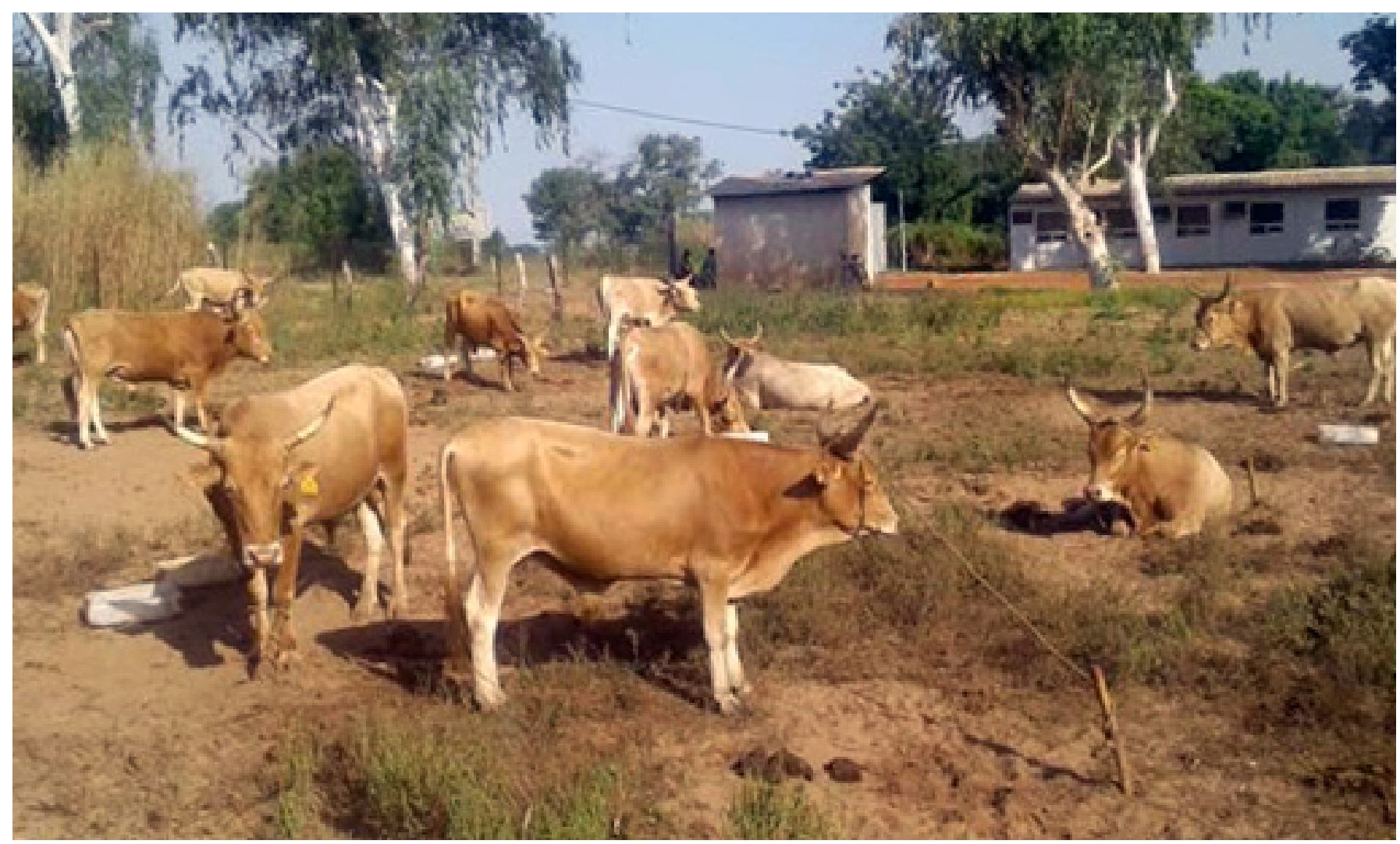

Figure 1. Selected N'Dama cattle breeding bulls in 2019 for the Multiplier tier. Photo: Arss Secka.

A genetic improvement programme using an Open Nucleus Breeding Scheme (ONBS) involving three tiers was therefore established in 1994 (Bosso, 2007) by the former International Trypanotolerance Centre (ITC), now called West Africa Livestock Innovation Centre (WALIC). The three implicated tiers are Nucleus, Multiplier and Commercial Farmer. The breeding goal of this ONBS is to increase the growth rate and milk yield of indigenous N'Dama cattle without losing their trypanotolerance and other adaptive traits (Jaitner and Dempfle, 1998). Similar breeding schemes for N'Dama cattle genetic improvement are also operational in southern Senegal, Guinea and Mali (Traoré et al, 2017; Camara et al, 2019; Ouédraogo et al, 2021).

This ONBS utilized a young sire scheme to determine the breeding values of young bulls under performance testing from weaning at 12 months of age up to 36 months within a high tsetse challenge area under similar management conditions as practised by community cattle herders. An animal model called Best Linear Unbiased Prediction (BLUP) was used for estimating breeding values for daily weight gain based on monthly weight from 15 to 36 months of age under high tsetse challenge, and the milk yield derived from the first 100 days of lactation was measured on a weekly basis (Bosso et al, 2009).

The young sire scheme was found to be as effective as the half-sib scheme where bulls are selected at the age of 5.5 to 6 years and better than the progeny testing scheme (Dempfle and Jaitner, 2000). These authors asserted that this scheme is also much simpler to implement, and does not require storing semen or having any waiting bulls.

The Multiplier tier farmers who received elite breeding N'Dama cattle bulls, Djallonké sheep rams, and West African Dwarf goat bucks around the country formed an association called Gambia Indigenous Livestock Multipliers Association (GILMA) in 2002, pulling together most of the farmers at the ONBS Multiplier tier. The main goal of this association was to coordinate multiplication activities of the disseminated breeding males at the Multiplier tier and further dissemination of their male offspring to the Commercial Farmer tier. The association has two main branches, each with its executive committee members, membership and bank account. The branch on the south bank of river Gambia is called GILMA Fulladou, whilst the one on the north bank is called GILMA Saloum. GILMA Associations were supported by ITC and now by WALIC in terms of capacity building, organizational setup and management, technical backup and financial support. After a few years of activity, the GILMAs became dormant in 2007 until ITC commissioned their institutional diagnosis in 2014.

To help revive the GILMAs, ITC/WALIC in collaboration with the West Africa Rural Foundation (WARF), the Regional Project for the Sustainable Management of Endemic Ruminant Livestock in West Africa (PROGEBE) and the Department of Livestock Services, conducted a thorough and exhaustive participatory institutional diag- 


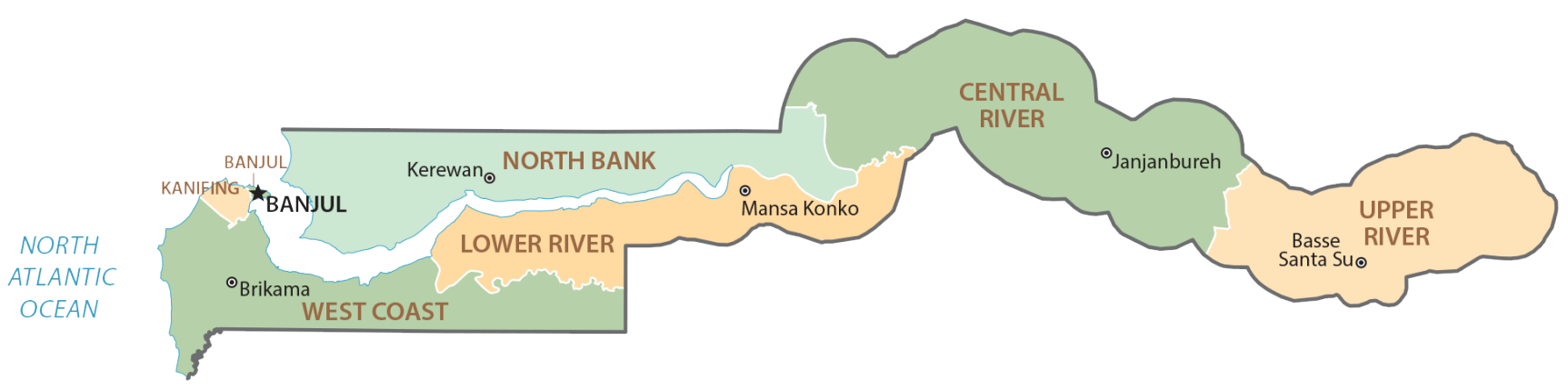

Figure 2. Map of The Gambia showing five administrative regions. Source: https://gisgeography.com/gambia-map/

nosis (PID) of the association in mid-February 2014. The overall objective of the PID was to develop a pathway for revitalizing the GILMAs into vibrant self-sustaining associations that would effectively carry out their roles and deliver on their responsibilities within the ITC/WALIC breeding programme. Findings showed a lack of clear vision and mission, and limited capacity of the executive committee members in the areas of institutional management, group facilitation, participatory planning, and effective strategic partnership and ownership (Olaniyan et al, 2015).

A participatory revitalization plan for the GILMAs was drawn up during the PID exercise. WARF proposed an action plan that involved strategic reflection, capacity building support and coaching/mentoring support to the associations (WARF, 2014). Under the WARF leadership, two workshops were convened in December 2016 and August 2017 with GILMA members for a strategic reflection on and elaboration of the vision, mission and annual work plan; and capacity building on organizational management and group facilitation, communications and information management, resource mobilization, financial management, and rural entrepreneurship respectively. The coaching support to both GILMA Saloum and GILMA Fulladou was carried out in November 2020. During the GILMAs' institutional management strengthening, ITC/WALIC had also conducted four technical capacity strengthening workshops for their membership covering animal breeding and selection, management, animal diseases recognition and control, feeds conservation, pasture production, compost pen construction (ITC, 2017), and hygienic milk collection and processing (ITC, 2018). There has been much improvement in the GILMAs' structural organization and management as well as their technical knowledge and capacity, but the associations have not yet reached the desired level of performance as a livestock breeding association vis-à-vis their vision and mission. The existence of similar breeders' association for the N'Dama cattle breed in Senegal, for Zebus (Azawak and Fulani cattle breeds), Baoulé, and Baoulé x Zebu Crosses in Burkina Faso have been reported (Ouédraogo et al, 2021).

The dissemination of elite breeding bulls from the Nucleus tier to the community Multiplier tier resumed in 2011, after a six-year break (2004-2010), through the intervention of and collaboration with a regional project on sustainable management of endemic ruminant livestock in West Africa, the PROGEBE project (2008-2014), that revived the breeding programme. From 2011 to 2019, a total of 52 elite N'Dama breeding bulls were disseminated to the multiplier farmers at various locations around the country. WALIC make regular biannual monitoring visits to maintain contact with farmers and check on the status of the disseminated breeding bulls. However, gaps exist in the overall profile of the multiplier farmers. The farmers' level of satisfaction or dissatisfaction with the disseminated bulls' general performance over nine years has not been reported. Therefore, this survey aimed at filling the gap by profiling multiplier farmers, assessing the performance of the disseminated elite N'Dama breeding bulls from 2011 to 2019, and inquiring about cattle health and production challenges confronting the farmers.

\section{Materials and Methods}

A five-day survey mission was undertaken in April 2020 to interview 40 farmers around the country who received 52 elite N'Dama breeding bulls from ITC/WALIC during the 2011-2019 period, and collect primary data on farmers' profiles, breeding bulls' performance, as well as cattle production and health challenges confronting the farmers. Thirty-three farmers in 33 villages located in five regions of The Gambia (Figure 2) were interviewed during the field mission. The remaining seven target farmers were either not available or had received breeding West Africa Dwarf goat bucks or Djallonke sheep rams whose information are not included in this article.

The target group of this survey was the Multiplier tier of the Open Nucleus Breeding Scheme (ONBS). This second tier of the ONBS consists of farmers whose cattle herds received and used elite N'Dama breeding bulls originating from the on-station WALIC Nucleus tier. As the name implies, the Multiplier tier's role is to produce more outstanding offspring breeding bulls for dissemination to the Commercial Farmer cattle herds around the country. 
Two sets of questionnaires were developed for this survey (Supplemental data). The first questionnaire was a checklist to collect information on farmers' names, village, bull identification number, bull introduction date, bull status, cattle herd size, number of cows in the herd, number of cows mated, number of calves sired, bull exit date and reason for the exit. The second questionnaire was divided into three sections. The first section asked for the beneficiary farmer profile, the second section dealt with account and performance of received animals, and the last section asked for cattle health and production challenges, and their perceived proposed solutions to address these challenges.

The questionnaires were written in English and administered through a face-to-face interview by the authors using common local dialects (Wollof, Mandinka and Fulla) since most of the farmers cannot read or write in English. These dialects are understood by both the interviewers and the interviewees. No intermediary translation was required. Four farmers were partly interviewed through telephone calls when some outstanding information could not be provided by members of the household met on the ground. Telephone calls were also made at times to follow up or verify collected data from the interviewed farmers.

All collected data were organized, sorted, analyzed, and summarized using descriptive statistics into tables and figures showing results of responses to various parameters of interest. The farmers' telephone numbers were used to create a WhatsApp group to serve as a communication platform. The information derived from the accounting of the disseminated bulls provides a record of their status and performance. The responses to the various questions were analyzed to deduce the performance of the bulls, the perceived cattle health and production challenges, and the farmers' proposed solutions to remedy stated challenges.

\section{Results}

\section{Profile of the Multiplier tier farmers}

The highest number of villages and farmers implicated in this Multiplier tier were found in the districts of Upper Fulladou West, Kiang West, and Niamina East. The age of the interviewed farmers ranged from 43 to 80 years. Out of the 33 farmers, only 2 were female, 3 had western tertiary education (2 Masters and 1 Doctorate holders), and 25 had access to WhatsApp either directly on their phones or a family member's living in the same compound (Table 1).

\section{Status of disseminated elite N'Dama breeding bulls}

A total of 52 elite N'Dama breeding bulls selected from the nucleus herd were disseminated to 35 cattle herds in the 33 villages distributed in 11 districts and 5 regions around The Gambia from 2011 to 2019 (Table 2 ). By April 2020, only 19 bulls were present in the multiplier cattle herds around the country (Supplemental Table 1).
Thirty-three bulls have exited from the community cattle herds due to various reasons such as culling (27\%), sales $(15 \%)$, death $(9 \%)$, accident $(9 \%)$, disease $(6 \%)$, low libido (6\%), loss (6\%), aggressiveness (6\%), and slaughter (3\%) (Supplemental Table 1). Bulls are usually culled after a maximum service period of five years in the same cattle herd as the male breeder. Culling reduced the chances of the bulls mating their daughters thus lowering the risk of inbreeding. Four hundred and seventy-three calves were reported to have been sired by the disseminated bulls from 2011 to 2019 (Table 2).

\section{Performance of disseminated breeding bulls}

Results of the questionnaire survey on the performance of breeding animals aggregated at national level are shown in Figure 3, which provides the results of the questionnaire survey on the performance of breeding animals aggregated at national level.

The health performance parameter measured the resilience of the disseminated bulls to endemic diseases versus other bulls from different sources. Twentyeight of the 33 respondents asserted that these bulls performed better health-wise than other bulls. The breeding performance parameter compared the libido and fertility of the disseminated bulls with others from different sources. Thirty-one of the 33 respondents affirmed that these bulls had stronger libido and fertility than other bulls. Similarly, the growth performance and milk production of disseminated bulls' offspring were reported faster and higher, respectively, than offspring from other sources. Farmers who received disseminated breeding bulls were satisfied $\mathrm{w}$ ith the general performance of the bulls with their offspring as asserted by 28 respondents compared to 5 respondents that expressed dissatisfaction.

However, most of the farmers had not disseminated mature offspring breeding bulls to Commercial Farmers' cattle herds for breeding purposes. Eight farmers had received bulls less than two years before the survey and had either not seen offspring or female offspring had not started lactating, therefore not responding to questions on offspring growth performance and milk production.

\section{Challenges confronting producers at the Multiplier tier}

Data collected from the interviewed farmers focusing on challenges and proposed solutions are presented in Table 3. Most of the health and production challenges highlighted include trypanosomiasis, low access to veterinary drugs and services, inadequate feed and water, bush fires and reduced grazing fields. These challenges could limit the performance of the disseminated animals at the multiplier cattle herds. Farmers' proposed solutions to addressing these challenges include moving towards intensive management of fewer animals for market-oriented enterprise; improving access to veterinary drugs and services; and general public sensitization to reduce bush fire incidents. 
Table 1. Profile of the 33 interviewed Multiplier tier farmers

\begin{tabular}{|c|c|c|c|c|c|c|c|c|}
\hline \multirow[t]{2}{*}{ Region } & \multirow[t]{2}{*}{ District } & \multirow[t]{2}{*}{$\begin{array}{l}\text { No. of } \\
\text { villages }\end{array}$} & \multirow[t]{2}{*}{$\begin{array}{l}\text { No. of farmers } \\
\text { interviewed }\end{array}$} & \multirow[t]{2}{*}{$\begin{array}{l}\text { No. of western- } \\
\text { educated farmers }\end{array}$} & \multirow[t]{2}{*}{$\begin{array}{l}\text { No. accessing } \\
\text { WhatsApp }\end{array}$} & \multicolumn{2}{|c|}{$\begin{array}{l}\text { Farmer's } \\
\text { gender }\end{array}$} & \multirow[t]{2}{*}{$\begin{array}{l}\text { Age range } \\
\text { (years) }\end{array}$} \\
\hline & & & & & & M & $\mathbf{F}$ & \\
\hline West Coast & $\begin{array}{l}\text { Kombo } \\
\text { East }\end{array}$ & 1 & 1 & 1 & 1 & 1 & 0 & 67 \\
\hline $\begin{array}{l}\text { Lower } \\
\text { River }\end{array}$ & $\begin{array}{l}\text { Kiang } \\
\text { West }\end{array}$ & 6 & 6 & 1 & 5 & 5 & 1 & $43-70$ \\
\hline $\begin{array}{l}\text { North } \\
\text { Bank }\end{array}$ & $\begin{array}{l}\text { Upper } \\
\text { Baddibu }\end{array}$ & 2 & 3 & 0 & 1 & 3 & 0 & $46-56$ \\
\hline \multirow[t]{7}{*}{$\begin{array}{l}\text { Central } \\
\text { River }\end{array}$} & $\begin{array}{l}\text { Upper } \\
\text { Saloum }\end{array}$ & 1 & 1 & 0 & 0 & 0 & 1 & 70 \\
\hline & Nianija & 4 & 4 & 0 & 4 & 4 & 0 & $55-80$ \\
\hline & Niani & 2 & 2 & 0 & 2 & 2 & 0 & $47-59$ \\
\hline & $\begin{array}{l}\text { Upper } \\
\text { Fulladou } \\
\text { west }\end{array}$ & 8 & 6 & 0 & 4 & 6 & 0 & $45-70$ \\
\hline & $\begin{array}{l}\text { Lower } \\
\text { Fulladou } \\
\text { west }\end{array}$ & 1 & 1 & 0 & 1 & 1 & 0 & 70 \\
\hline & $\begin{array}{l}\text { Niamina } \\
\text { East }\end{array}$ & 5 & 5 & 0 & 5 & 5 & 0 & $43-66$ \\
\hline & $\begin{array}{l}\text { Niamina } \\
\text { West }\end{array}$ & 1 & 1 & 0 & 0 & 1 & 0 & 60 \\
\hline $\begin{array}{l}\text { Upper } \\
\text { River }\end{array}$ & Sandu & 2 & 3 & 1 & 2 & 3 & 0 & $54-60$ \\
\hline Total & 11 & 33 & 33 & 3 & 25 & 31 & 2 & $43-80$ \\
\hline
\end{tabular}

Table 2. Account of disseminated bulls at the Multiplier tier. Additional details are provided in Supplemental Table 1.

\begin{tabular}{|c|c|c|c|c|c|c|}
\hline Regions & Districts & $\begin{array}{l}\text { No. of } \\
\text { villages }\end{array}$ & $\begin{array}{l}\text { No. of cattle } \\
\text { herds implicated }\end{array}$ & $\begin{array}{l}\text { No. of bulls } \\
\text { supplied } \\
(2011-2019)\end{array}$ & $\begin{array}{l}\text { No. of bulls } \\
\text { present in } \\
2020\end{array}$ & $\begin{array}{l}\text { No. of calves } \\
\text { sired } \\
(2011-2019)\end{array}$ \\
\hline West Coast & Kombo East & 1 & 1 & 2 & 1 & 24 \\
\hline Lower River & Kiang West & 6 & 6 & 6 & 2 & 64 \\
\hline North Bank & $\begin{array}{l}\text { Upper } \\
\text { Baddibu }\end{array}$ & 2 & 3 & 4 & 2 & 105 \\
\hline \multirow[t]{7}{*}{ Central River } & Upper Saloum & 1 & 1 & 1 & 1 & 0 \\
\hline & Nianija & 4 & 4 & 4 & 0 & 145 \\
\hline & Niani & 2 & 3 & 3 & 3 & 24 \\
\hline & $\begin{array}{l}\text { Upper } \\
\text { Fulladou West }\end{array}$ & 8 & 7 & 16 & 4 & 38 \\
\hline & $\begin{array}{l}\text { Lower } \\
\text { Fulladou West }\end{array}$ & 1 & 1 & 2 & 2 & 0 \\
\hline & Niamina East & 5 & 5 & 9 & 2 & 25 \\
\hline & Niamina West & 1 & 1 & 1 & 0 & 28 \\
\hline Upper River & Sandu & 2 & 3 & 4 & 2 & 20 \\
\hline Total & 11 & 33 & 35 & 52 & 19 & 473 \\
\hline
\end{tabular}




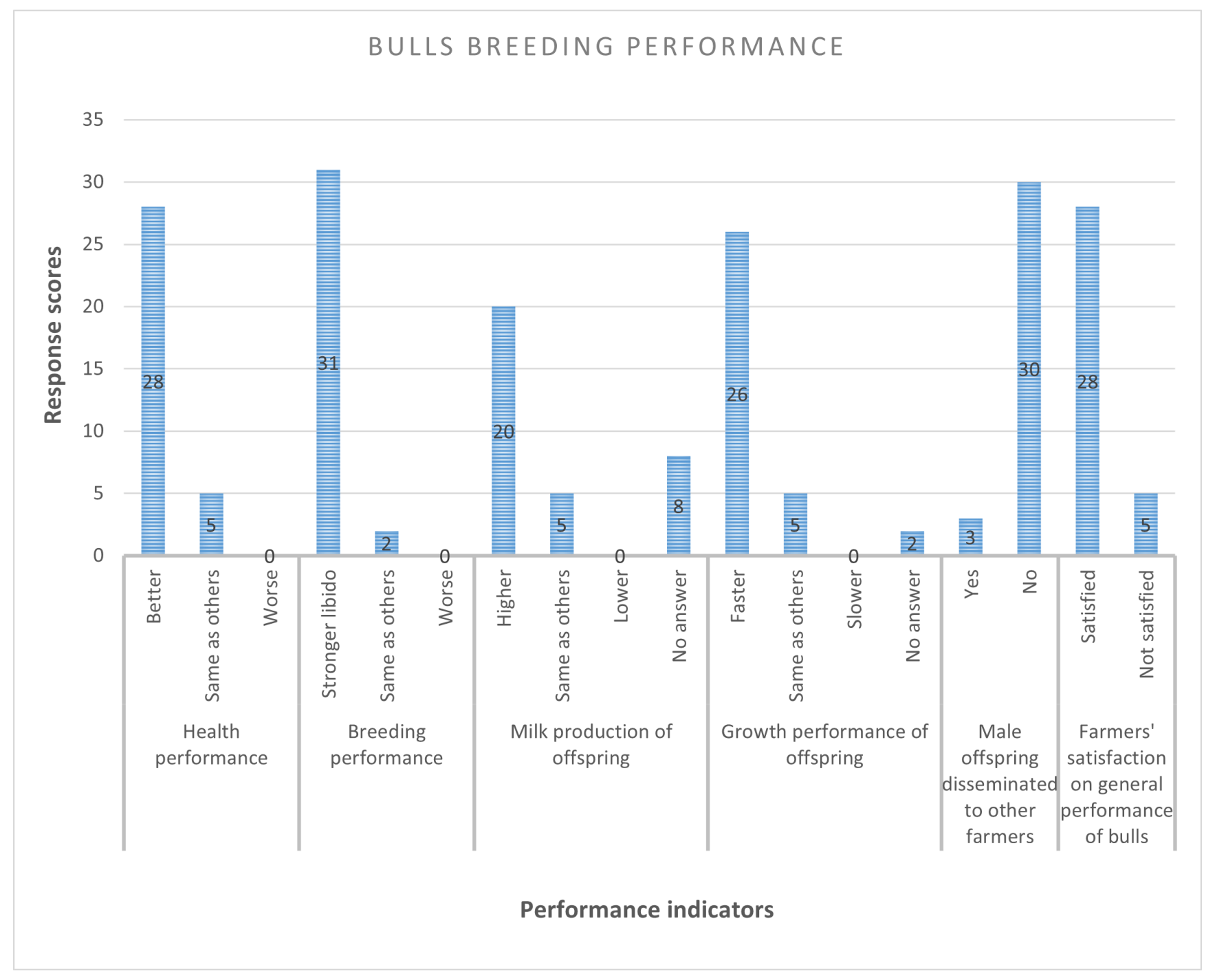

Figure 3. Responses of 33 Multiplier tier farmers to bulls breeding performance indicators

Table 3. Challenges confronting livestock producers and proposed solutions

\begin{tabular}{|c|c|c|c|c|c|c|}
\hline Region & $\begin{array}{l}\text { No. of } \\
\text { districts }\end{array}$ & $\begin{array}{l}\text { No. of farmers } \\
\text { interviewed }\end{array}$ & $\begin{array}{l}\text { Health } \\
\text { challenges }\end{array}$ & $\begin{array}{l}\text { Production } \\
\text { challenges }\end{array}$ & $\begin{array}{l}\text { Marketing } \\
\text { challenges }\end{array}$ & Proposed solutions \\
\hline $\begin{array}{l}\text { West } \\
\text { Coast }\end{array}$ & 1 & 1 & None & $\begin{array}{l}\text { Lack of sufficient } \\
\text { land for free } \\
\text { grazing of cattle }\end{array}$ & None & $\begin{array}{l}\text { Introduce techniques of } \\
\text { intensive production using } \\
\text { exotic breeds to increase } \\
\text { milk and meat production }\end{array}$ \\
\hline $\begin{array}{l}\text { Lower } \\
\text { River }\end{array}$ & 2 & 5 & $\begin{array}{l}\text { Access to } \\
\text { veterinary drugs }\end{array}$ & $\begin{array}{l}\text { Bush fires causing } \\
\text { feed shortages } \\
\text { during the dry } \\
\text { season }\end{array}$ & None & $\begin{array}{l}\text { Improve access to } \\
\text { veterinary drugs and } \\
\text { services. Sensitization } \\
\text { activities to reduce } \\
\text { bushfires in the dry } \\
\text { seasons especially in } \\
\text { Kiang West District }\end{array}$ \\
\hline $\begin{array}{l}\text { North } \\
\text { Bank }\end{array}$ & 1 & 3 & $\begin{array}{l}\text { Trypanosomiasis } \\
\text { infections in dry } \\
\text { seasons }\end{array}$ & $\begin{array}{l}\text { Insufficient clean } \\
\text { drinking water for } \\
\text { the cattle during } \\
\text { the dry season }\end{array}$ & None & $\begin{array}{l}\text { Improve access to } \\
\text { veterinary drugs and } \\
\text { provision of drinking } \\
\text { points for cattle }\end{array}$ \\
\hline $\begin{array}{l}\text { Central } \\
\text { River }\end{array}$ & 6 & 21 & $\begin{array}{l}\text { Access to } \\
\text { veterinary drugs }\end{array}$ & $\begin{array}{l}\text { Insufficient } \\
\text { grazing lands }\end{array}$ & None & $\begin{array}{l}\text { Improved access to } \\
\text { veterinary services and } \\
\text { drugs. }\end{array}$ \\
\hline $\begin{array}{l}\text { Upper } \\
\text { River }\end{array}$ & 1 & 3 & None & $\begin{array}{l}\text { Lack of clean } \\
\text { drinking water }\end{array}$ & None & $\begin{array}{l}\text { Provide cattle drinking } \\
\text { points }\end{array}$ \\
\hline
\end{tabular}




\section{Discussion}

\section{Multiplier tier farmers' profile}

Among the 33 farmers who were interviewed, 30 were illiterate in the English language, whilst three are highly educated professionals in the western form of education system. The presence of only 2 women out of 33 interviewed farmers show that male farmers dominate the ONBS cattle Multiplier tier around the country. This observation follows the national pattern of males dominating the ownership of cattle production and management in The Gambia. The age of the interviewed multiplier farmers ranging from 43 to 80 years is indicative of the ages of the household heads. In most instances, the head of the family owns the disseminated elite breeding bulls. However, the daily management of the cattle herds rests on the shoulders of younger family members or contracted herdsmen.

\section{Account of disseminated bulls}

The districts of Upper Fulladou West, Niamina East, Kiang West, and Nianija received most of the disseminated bulls. This observed distribution pattern is explained by the fact that the first three districts have been participating in many ITC/WALIC activities, particularly the genetic improvement programme. Moreover, the districts of Kiang West, Niamina East and Nianija were also intervention sites of the Regional project for the Sustainable Management of Endemic Ruminant Livestock in West Africa (PROGEBE) in 2008-2014, which had a component of supplying improved breeding bulls from ITC/WALIC to their contact cattle farmers. Out of the 52 disseminated bulls, as of April 2020, only 19 were present in Multiplier cattle herds due to various reasons, as shown in Table 2.

\section{Performance of disseminated breeding bulls}

The findings on the breeding performance of disseminated bulls at the Multiplier tier showed that the breeding programme was attaining its target breeding goal of increased growth rate and milk offtake without compromising the tolerance to endemic diseases like trypanosomiasis. Both the health and breeding performance of the disseminated bulls at the Multiplier tier got high scores from the respondents. Therefore, it appears that the high genetic potential for higher growth rate and milk offtake contained in these bulls had been transferred to their offspring.

This survey's findings corroborate a survey conducted in 2003, which assessed the adoption and impact of the ITC/WALIC genetic improvement programme at the Multiplier tier (Agyemang, 2003). Findings from the 2003 survey showed that participating villages, associations and households were pleased with the benefits from the improvement programme and disseminated breeding bulls performed well under village conditions. All participating respondents believed that the use of improved N'Dama bulls would improve their livelihoods. Although the genetic gains at the
Multiplier tier had not been calculated during the 2003 survey, Mattioli et al (1998) found that from 1994 to 2004 the estimated average breeding values for weight at 36 months ranged between 0 to $6.32 \mathrm{~kg}$ at the Nucleus tier. They further asserted that weight at 36 months showed the highest genetic gain with a response of $0.40 \mathrm{~kg}$ per year. Hence, it is highly probable that the bulls disseminated to the multiplier farmers from 2011 to 2019 may have had similar or higher genetic gains for weight at 36 months.

Siring many calves at the Multiplier tier cattle herds is one of the ultimate aims of disseminating improved breeding N'Dama bulls from the Nucleus tier. Disseminated bulls during this period have sired a total of 473 healthy and strong calves. Further dissemination of bulls' male offspring from the Multiplier tier to the Commercial Farmer tier was found to be limited - only two offspring bulls in 2018 and one in 2019. This challenge has been recognized for some years now and efforts have been taken to remedy the situation. Institutional diagnostics of GILMAs in 2014 showed that there are many organizational, management, capacity and financial limitations affecting the association. Activities for strengthening the GILMAs have been implemented and hopefully, this situation of low transmission of breeding bulls from the Multiplier tier to the Commercial Farmer tier will improve in the near future. It also appears that many livestock farmers are not aware of the WALIC breeding programme. This calls for more sensitization of farmers and increased visibility of the programme. Artificial i nsemination is also a faster reproductive tool where stored semen from bulls could be used in many cows for a longer duration than live bulls.

\section{Challenges confronting livestock producers}

The expression of disseminated bulls' genetic values could be affected by environmental factors such as feed, management, water, changing climate and diseasecausing pathogens. Various challenges on health, production and marketing were assessed during this survey. Although there seem to be no marketing challenges, respondents asserted some challenges under health and production domains. Access to veterinary drugs was reported as a limitation in both Central River and Lower River Regions. This could be explained by the fact that private veterinary drug outlets operating in these regions are located mainly in towns and big villages, whilst these farmers are mostly residing in small villages. However, they could still travel to the veterinary outlets or call the public livestock officers to attend to their animals' health needs.

Trypanosomiasis was mentioned as a challenge in North Bank Region particularly during the dry season when the animals are nutritionally stressed. N'Dama cattle are trypanotolerant, hence would still survive and produce in trypanosomiasis prevalent areas (Mattioli et al, 1998). 
The major highlighted cattle production challenges were inadequate grazing lands, the occurrence of bush fires ravaging pastures and rangelands, and insufficient cattle drinking points. These challenges are very serious factors that could retard the progression of increased livestock productivity at both Multiplier and Commercial Farmer tiers. Adequate good-quality feed and water are essential for growth, maintenance and production. Grazing lands are dwindling, resulting from increasing human population pressure and associated competing agro-industrial and residential activities. Conflicts may arise between pastoralists and farmers during cropping seasons as access routes to the grazing areas are often blocked. This situation leads to the transhumance of cattle to other regions in The Gambia or the surrounding Republic of Senegal. Cattle drinking points are limited and these negative impacts are felt during the long dry season.

Many solutions were proposed by the respondents to solve these challenges. They include the use of exotic cattle breeds under intensive management for increased meat and milk production; community sensitizations to stop the harmful practice of bush fires; government support for the provision of cattle watering points; and improving access to veterinary services and drugs. Embracing the proposed solutions requires capital investment from farmers, the private and public sectors, and non-governmental organizations (NGOs). There are some initiatives taken up by the government and development partners to address these challenges and are registering some significant progress.

\section{Conclusion}

Although the survey has used mainly qualitative data obtained from farmers' perceptions and recollections and not backed by longitudinal quantitative production data, it has provided some important insights about Multiplier tier farmers, the performance of disseminated bulls, and constraints limiting cattle production and productivity.

The survey has profiled the farmers involved in the ongoing breeding programme and the general performance of the disseminated bulls at the Multiplier tier. Farmers - more than 40 years old, predominantly male and very few with higher education - generally practise subsistence farming and extensive management of N'Dama cattle herds combined with the cultivation of crops. Farmers are generally satisfied with the health and breeding performances of the disseminated breeding bulls at the Multiplier tier. They have asserted that both the growth rate and milk outputs of these bulls' offspring are higher than those from other bulls. Only three offspring bulls were disseminated from the Multiplier tier farmers to the Commercial Farmer tier cattle herds as breeders. This figure is very low and therefore the following actions are proposed: 1) more sensitization of farmers, 2) increased visibility of the breeding programme, and 3) use of other dissemination tools such as artificial insemination that could reach more cows for enhanced genetic improvement and productivity.

Major health challenges mentioned by the farmers include trypanosomiasis and inadequate access to veterinary services and drugs. On production challenges, issues include insufficient grazing lands, frequent bush fires ravaging large amounts of fodder, and insufficient livestock watering points during the long dry season. Many initiatives are taken by individual farmers, communities, private and public sector-led projects to address prevailing livestock production and health challenges. The Gambia Indigenous Multipliers Association (GILMA) has been found weak, and activities were conducted to revamp this association to facilitate and sustain the transfer of improved genetic gains across the three-tier open nucleus breeding scheme.

\section{Acknowledgements}

The authors are grateful to the Government of The Gambia for providing financial support in the form of monthly subventions that keep the WALIC staff personnel on board and facilitated travel costs for the collection of data during the survey period.

\section{Supplemental Data}

Questionnaires used in farmer's survey:

Questionnaire 1: Check list for disseminated bulls

Questionnaire 2: Performance of elite N'Dama breeding bulls at the Multiplier tier

Supplemental Table. Checklist data on account of disseminated bulls

Translated Abstract in French

\section{Author contributions}

Arss Secka coordinated the survey, took part in the collection, collation and analysis of data from farmers, and drafted the article manuscript. Lamin Camara provided inputs into the manuscript and participated in the collection, collation and analysis of data from farmers. Momodou Jeng provided inputs into the manuscript and participated in the data collection from farmers. Olawale Olaniyan provided inputs into the manuscript.

\section{Conflict of interest statement}

The authors declared that there is no conflict of interest.

\section{References}

Agyemang, K. (2003). Improved Performance in Trypanotolerant Livestock. Final Project Report of BMZ/GTZ funded project.

Bosso, N. (2007). The N'Dama cattle genetic improvement programme: A review. Animal Genetic Resources Information 40, 65-69. doi: https://doi.org/ $10.1017 /$ S1014233900002200 
Bosso, N. A., Van Der Waaij, E. H., Kahi, A. K., and Van Arendonk, J. A. M. (2009). Genetic analyses of N'Dama cattle breed selection schemes. Livestock Research for Rural Development 21(8). url: http:// www.lrrd.org/lrrd21/8/boss21135.htm.

Camara, Y., Moula, N., Sow, F., Sissokho, M. M., and Antoine-Moussiaux, N. (2019). Analysing innovations among cattle smallholders to evaluate the adequacy of breeding programs. Animal 13(2), 417-426. doi: https://doi.org/10.1017/S1751731118001544

Dempfle, L. and Jaitner, J. (2000). Case Study about the N'Dama breeding programme at the International Trypanotolerance Centre (ITC) in The Gambia. In Galal, S., Boyazoglu, J., and Hammond, K., Developing Breeding Strategies for Lower Input Animal Production Environments. Proc. of an International Workshop, Bella (Italy), 22-25 September 1999, volume 3 of ICAR Technical Series, ICAR, Rome, Italy, 347-354.

ITC (2017). ITC Annual Report 2017 and Outlook 2018. International Trypanotolerance Centre, Banjul, The Gambia.

ITC (2018). ITC Annual Report 2018 and Outlook 2019. International Trypanotolerance Centre, Banjul, The Gambia.

Jaitner, J. and Dempfle, L. (1998). A breeding scheme for the indigenous N'Dama cattle. In Proceedings of the 49th annual meeting of the EAAP, 24-27 August 1998, Warsaw, Poland, 42p.

Mattioli, R. C., Jaitner, J., Clifford, D. J., Pandey, V. S., and Verhulst, A. (1998). Trypanosome infections and tick infestations: susceptibility in N'Dama, Gobra zebu and Gobra x N'Dama crossbred cattle exposed to natural challenge and maintained under high and low surveillance of trypanosome infections. Acta Tropica (1), 57-71. doi: https://doi.org/10.1016/ s0001-706x(98)00051-5

Olaniyan, O. F., Fall-Diop, N. N., B, F., Secka, A., Smith, O. B., and Kebbeh, M. (2015). Assessment of institutional capacities of the Gambia Indigenous Livestock Multipliers' Association. Animal Genetic Resources 57, 119-126. doi: https://doi.org/10.1017/ S207863361500020X

Olaniyan, O. F., Kaya, I., and Secka, A. (2021). Trypanosomosis prevalence in natural field-based infection: insights into systematic review and metaanalysis of studies from 1980 to 2018 on The Gambian ruminants with special emphasis on cattle. Tropical Animal Health and Production (25), 53-53. doi: https: //doi.org/10.1007/s11250-020-02461-w

Ouédraogo, D., Soudré, A., Yougbaré, B., OuédraogoKoné, S., Zoma-Traoré, B., Khayatzadeh, N., Traoré, A., Sanou, M., Mészáros, G., Burger, P. A., Mwai, O. A., Wurzinger, M., and Sölkner, J. (2021). Genetic Improvement of Local Cattle Breeds in West Africa: A review of Breeding Programs. Sustainability 13(4), 2125. doi: https://doi.org/10.3390/su13042125

Secka, A., Gibba, P., Ceesay, A., Bojang, M., Jarju, A., and Gaye, M. (2015). Effects of changing climate and vegetation on trypanosomosis burden in The
Gambia. Bulletin of Animal Health and Production 63(3), 335-367. url: http://repository.au-ibar.org/ handle/123456789/476.

Traoré, S. A., Markemann, A., Reiber, C., Piepho, H. P., and Valle Zárate, A. (2017). Production objectives, trait and breed preferences of farmers keeping N'Dama, Fulani Zebu and crossbred cattle and implications for breeding programs. Animal 11(4), 687-695. doi: https://doi.org/10.1017/S1751731116002196

WARF (2014). Participatory Institutional Diagnosis of Gambia Indigenous Multipliers Association. West Africa Rural Foundation, Senegal and International Trypanotolerance Centre, The Gambia. 